\title{
UTHLTY, RIGHTS
}

\section{AND THE DOMESTIC VIRTUES: or}

\section{What's Wrong with Raymond}

\author{
Stephen R. L. Clark \\ University of Liverpool
}

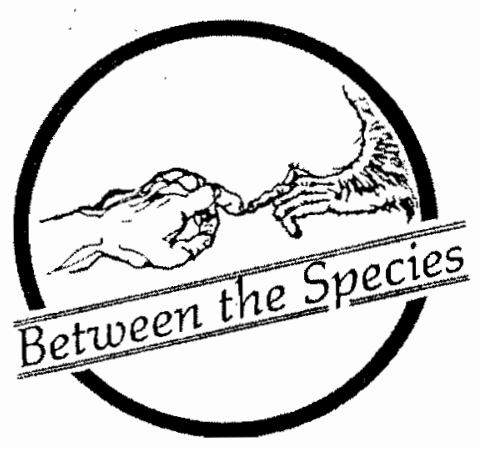

I

Those who know Raymond Frey and myself only through our writings usually suppose that we must be on very bad terms and were doubtless expecting a very acrimonious debate to open the Wolfson Lecture series in Oxford in the autumn of 1986. In fact we are friends and sometime colleagues. It is clear that we disagree on many issues, not least the treatment of animals, but we don't necessarily disagree for the reasons and in the ways that others sometimes suppose. We are both opposed to irrationalism, to the fashionable doctrine that there can be no moral or other arguments worth considering. We are both opposed to the related dogma of amoralism, the idea that no moral conclusions are worth taking seriously, whether because there are no "moral facts" or because no one ever "really" acts morally or for moral reasons. There are people who habitually condemn what they describe as "moralizing," without ever noticing that precisely by condemning such behaviour, they are themselves engaged in the practice they condemn. Those same people generally have very definite (and

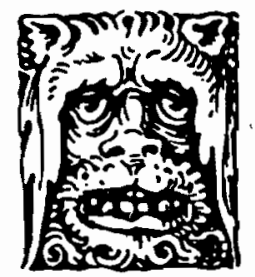

\section{PHILOSOPHY}


plainly moral) views about a wide variety of dubious practices: rape or child-abuse or racial discrimination. Both of us believe that it is important to make our decisions after due consideration of the relevant evidence and of the principles by which we act. Both of us accept that there are some things that we would not be prepared to countenance and some implications of proposed moral principles that amount to a practical refutation of those principles: no one should be allowed to excuse herself from the duty of moral thought by pleading that she was only following orders or the existing guidelines. Neither of us, even if we occasionally indulge our more rhetorical selves, as I have just done, thinks it appropriate merely to abuse our opponents though both of us, faced by recalcitrant immoralists, have been reduced on occasion to reminding people of what the Nazis and their fellow-travellers did, and on what pretexts!

\section{Confronted by invasive experiments on chimpanzees and mentally defective human beings, Frey would conclude that one set of experiments was justified only if the other set also was.}

In all this I have said no more than that Frey and I are both philosophers, professionally and personally inclined to use and to criticize arguments, and to follow those arguments where they lead, even if that is to unfashionable places. Frey may well be more extreme than I, despite his reputation in certain quarters as a stout defender of common sense against "foolish animal liberationists." For the odd thing is, as I shall emphasize in a moment, that Frey is regularly welcomed as an opponent of "animal rights" by people (e.g., Rothbard 1982, pp. 155ff) who have failed to notice that he is also opposed to human rights and that he is in fact as much an antispeciesist as I am (and maybe more so). Confronted by invasive experiments on, say, chimpanzees and mentally defective human beings, Frey would use very much the same calculations as Peter Singer and conclude that one set of experiments was justified only if the other set also was. He has no different moral principles to use about "animals" than about "humans" and would allow such invasive experiments on the humans if there was good reason to think that a net general advantage could be gained by them. Where I might acknowledge the very real inhibitions and historical precedents that prevent most of us from being happy with such experimental use of humans, Frey would think us wrong to treat them any differently from chimpanzees - and experiment on them both. Whereas I wish chimpanzees (and other creatures) to be treated in something like the way that we presently treat humans, Frey wishes humans to be treated in something like the way we presently treat animals. Neither of us thinks that radically different rules apply to creatures of different species, except insofar as their differences mean that what is an injury in the one case is not an injury at all in another (cows, for example, are not injured by being confined within the county of Devon: Singer 1985, p. 6).

That we are both philosophers means that we both recognize the virtues of abstract argument, divorced from the day to day pressures that bear upon those who must make quick decisions (although we also both recognize that there are such pressures and that it is often up to the daily practitioner of an art to take responsibility for those decisions: how, for example, to deploy scarce medical resources). It also means that we make it our business to connect pieces of information from many different fields, to notice that what is said in one region of the world of letters must have repercussions for what is said elsewhere. Neither of us can quite manage, as a general rule, to isolate the results of evolutionary theory so that "non-humans" are reckoned to be members of one and the same evolutionary system as humans and at the same time of such a radically different kind that radically different morals apply to them. What it is wrong to do to a recently discovered human tribe may also be wrong to do to a nonhuman troop. If we justify the use of chimpanzees as experimental subjects (because it 
gives "us" an advantage or increases "our" knowledge), we should notice what we are saying about invasive treatment of Amazonian tribes and be ready to point to some credible and morally relevant difference between the cases if we wish to use different rules.

So how do Frey and I differ, and how is it reasonable to differ about the treatment of our nonhuman kin? It is perhaps best to approach that question by asking first how other spokesmen for "animal rights," broadly so called, might express their differences. How do Peter Singer or Tom Regan stand against Frey? As I have already suggested, Singer and Frey are both utilitarians, both antispeciesists. Both believe that that action is correct which, in the circumstances, is likeliest to lead to the largest net satisfaction of preferences amongst those affected by the act. Both agree that animal pains and pleasures count towards this calculation, as Bentham and J.S. Mill proposed long ago. Classical utilitarians were not speciesist, nor did they suppose that just any human pleasure was worth any amount of animal pain. The gradual legislative process that outlawed cruel treatment of domestic and other animals owed a lot to utilitarian calculation and the associated rejection of traditional discriminations. Frey and Singer are agreed in this. For that matter they are also agreed in thinking that most nonhumans have so little grasp of the future and of their own selfhood that they are not injured by being deprived of a "naturally long life." So long as other chickens, just as "happy" as the last, are brought into being, there is no wrong done, in Singer's terms, by killing some. All utilitarians tend to have some difficulty with the injury supposedly done by killing: there is an injury only if someone's preferences are thereby denied or their states of mind rendered more disagreeable. Those who don't know about their coming death and have no long-term projects are not injured by it. As good utilitarians, neither Frey nor Singer believes in "rights"; if there is a particular action that would, all things considered, lead to a "better" outcome, no one has a right to veto it. I cannot claim that there is anything which is "my" property alone, such that I may justly refuse its help to others. If everyone would, all things considered, be better off if what is called "my" property, "my" life, "my" body, "my" purposes were otherwise deployed, then I may justly be forced to do my utilitarian duty. So also may animals. The only question is whether some particular practice does in fact provide a net utilitarian advantage. Frey believes that most of our present practices (but not all) do; Singer thinks that many (but not all) do not. In the last resort the difference is not one of principle but of present calculation: how much worse is the present situation than some ideal result, and how difficult, how costly, would it be to get nearer the ideal? I can see no morally neutral way of settling this dispute.

That, of course, is the problem. Utilitarian calculation was originally offered as a simple, morally neutral way of deciding which was the "better" outcome, morally neutral in the sense that anyone could agree upon the result, whatever her personal moral (or other) preferences. It seems an obvious thought: that change is to be preferred that leaves someone better off and no one worse off, that satisfies someone's desires without causing any positive distress. Where that ideal is unobtainable, we had better vote on it, taking due account of the strength of feeling in those affected. How else would we decide whether to have Rum Raisin or Chocolate Chip ice cream than by asking what is wanted, with what strength? The trouble is, once we are past such simple and genuinely neutral calculations, the result is impossible to calculate. We have no way of deciding who is how much happier as a result of what action, over the long run. We have no way of doing so partly, and crucially, because how happy they will be depends in part on their own original moral assessments. If a good many people are made unhappy by, strongly disapprove of, for example, bear-baiting or beating donkeys to death, then it may be a utilitarian goal to end such practices. If they are not too bothered by the sight or thought of donkeys dying in pain, there may be a utilitarian advantage in allowing owners thus to let off steam. Whether to ban the practice depends covertly on the prior judgments of those involved. If people think it wrong enough, utilitarians will seek to ban it; if they don't, they won't - but this obviously does not help at all in deciding whether or not to disapprove of it in the first place.

On the surface, Singer and Frey differ simply in their calculations of the utilitarian greater good, but the fact is that neither of them can satisfactorily perform such a calculation, least of all without 
reference to a prior, non-utilitarian assessment of what is to be done. I may as well admit that in my judgment Frey has the technical victory here: even if some other farming practices than the present ones were, all told, a better option, there is precious little reason to think that any single act of mine would lead to the amelioration of those present practices. So I can have no utilitarianly grounded obligation to give up eating flesh, to campaign against what ideally would be reckoned an inferior result, or to castigate those who make a different calculation. Where I differ from Frey is that this very point seems to me a refutation of utilitarianism, for it applies to every other area of life. Nothing I can ever hope to do will have, in the long run, much effect on the general welfare, and no moral dilemma is easily resolvable in terms of the net welfare consequent upon each of the alternative actions. Utilitarianism is therefore, in my judgment, a wholly empty program. People who think they are utilitarians have actually chosen their particular futures on quite different grounds.

\section{1}

So how would Tom Regan disagree with Frey? Regan has often expressed some irritation, reasonably enough, that the slogan "animal rights" is commonly attributed to Singer (Regan 1986, pp. 94ff). Singer, as I have just pointed out, has no more time for "natural rights" than Frey, and the arguments, such as they are, for agreeing that "animals" have such rights are not Singer's at all but Regan's or Henry Salt's (Regan 1983; Salt 1980). It is Regan who thinks that all those animals who may reasonably be considered "subjects-of-a-life" have just the same "natural rights" as, we suppose, all humans have: we hold this truth to be self-evident, that all subjects-of-a-life are created equal, and have equal rights to life, liberty and the pursuit of happiness. Each such subject has the right to veto certain practices upon its person or property, whatever the supposed advantages to others. Each such subject has just the same rights, in nature, as all others, and no state authority, conversely, has any right to violate those rights. Even if great advantages could indeed be won by experimenting upon some such subject without her consent, this should not be done, because we could not will that every such subject should thus be at the disposal of all others.
To be a subject-of-a-life is to be an end in oneself, just as Kant supposed. Kant's error was in thinking that only human subjects were ends in themselves. There is no discoverable difference between all humans and all nonhumans that would license different moral treatment. Regan, in brief, is opposed to both Frey and Singer: where both those latter wish humans to be treated roughly as we now treat animals (with an eye to aggregated utility), Regan wishes animals (some animals) to be treated more as we now treat humans.

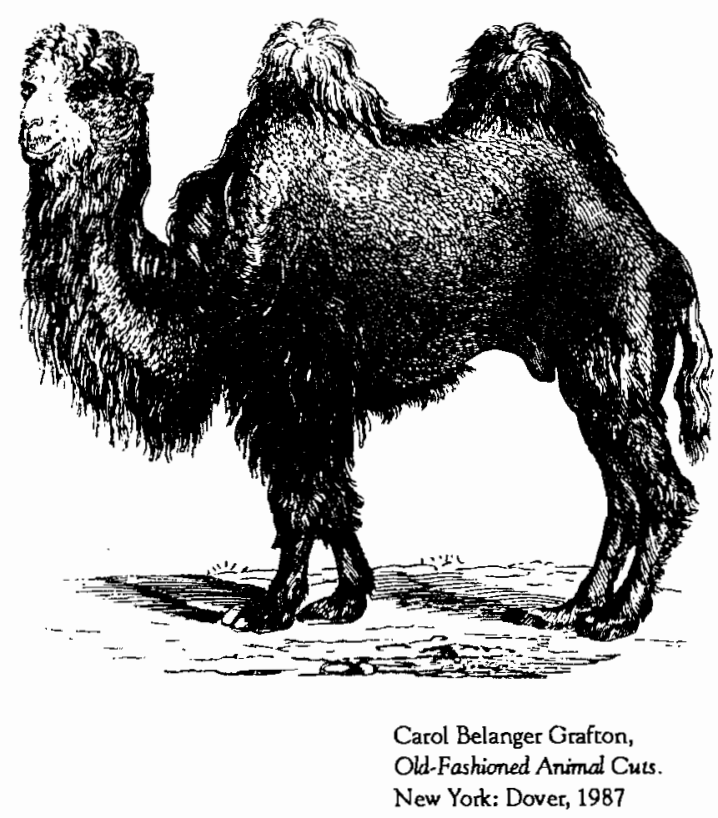

Human rights are usually invoked to bar the sort of simple-mindedly utilitarian calculation that denies any property in her own life, body and possessions to an individual and also to define the proper limits of governmental interference. Rights are those claims and entitlements that the law may properly be invoked to protect. Good liberals do not suppose that governments have any right to control their subjects' lives absolutely or to interfere between a person and her "private morals." What we do on "our own time," with our "own" bodies and possessions, is "our business," unless and until we violate the rights (and not simply damage the interests or offend the moral sensibility) of another. Right-wing liberals deny even any governmental 
right to redistribute income or secure the welfare of the needy; left-wing or "welfare" liberals prefer to think that we have welfare rights (of recipience) as well as liberty rights (of action) - so that the "right to work" means something quite different in rightand left-wing propaganda. Both sides agree that governments ought not to legislate simply for the general welfare, however defined, but to protect the rights of subjects. Those rights are not simply created by governmental action; we do not readily agree that regimes that regularly "violate human rights" are really doing no such thing but simply failing to create such rights. Any particular government does wrong if it legislates against the lives and liberties of its subjects or fails to legislate in their favor.

This is why animal welfare legislation was opposed in the nineteenth century even by good liberals who had no personal interest in maltreating animals; since only humans had rights in this strong sense, the law had no business defending a donkey against its owner or a badger against anyone who could carch it. We might disapprove, as we also disapprove of lying, drunkenness, infidelity, deliberate stupidity, or a failure to look after the fabric of one's house. But unless such vices issue in particular acts that violate the rightful expectations of others they are not our business. So those who managed to get animal welfare legislation on the books did so in the full consciousness that they were endorsing the state's right to legislate on "moral" matters (and did not need any longer to speak of rights at all). Others solved the crux by insisting that animals (or some animals) had rights for just the same reasons that humans did (see Nicholson 1879, p. 16).

This second path is made more attractive by the argument from "marginal cases" - a title that I confess I think is misleading and even offensive. Kant identified the ground of "rights" as our respect for the rational in all its embodiments, and social contract theorists suggested that rights were what any self-seeking rational individuals would insist upon writing into the social contract. Both accounts leave infants, imbeciles, lunatics, the senile on the fringes. None of these can be said to be actually (even if potentially) rational, and none of them needs to be taken account of by self-seeking rational individualists. If only rational beings have rights, because only such rational beings have any prospect of ever forcing their claims upon us, then such "marginal humans" have no rights. If "we" treat them fairly well, if we do, it is only because we have certain sentimental attachments of a kind that "we" seek to enforce on others even if such legislation is not strictly in accord with liberal principle. We might similarly force people to keep certain standards of animal care but not because we think that either animals or imbeciles have rights in their own right. A government that failed to protect them would be within its rights; a government that did too much to protect them would not be.

Some philosophers, including Frey, have been ready to accept at least in principle that there would indeed be no absolute wrong done in breeding babies for the luxury restaurant market or experimenting invasively on imbeciles: after all, they wouldn't exist at all if we didn't plan to use them like that, and anyway they are not intelligent enough to understand and object to what we're doing.... Our not doing this rests only on the moral outrage and personal discomfort such a practice would generate here-now. Those who think that such practices would be wrong, such as to be resisted by any competent agent, even if no one was much offended by them, have to agree that something of the same wrong would be done (is done) in invasive experimentation on chimpanzees or breeding farm animals for food. The wrong is simply that we thereby do things that deny to our victims the life that they might otherwise lead, do things to them that cause them distress and pain, treat them as if they were our property and not their own. If human imbeciles ought so far as is possible to be allowed or assisted to live their own lives, why should not nonhuman creatures be allowed or assisted so to do? It is not only rationality that deserves respect but the individual dignity of each subject-of-a-life.

There are, of course, difficulties with this doctrine. Animal-loving utilitarians were concerned about the pains and pleasures of their clients and were simultaneously prepared to legislate to protect them and to treat them aggregatively, for the common good. Rights theorists think that more matters than mere pain and pleasure. We ought to act according to those maxims that we can conceive to be universal' law. Rights are those claims and entitlements that can be conceived to be preserved 
without contradiction: every human's rights are compatible with every other human's rights, even if our interests aren't. So an animal's rights, supposing that it is granted that he has at least as many as a human imbecile, will include more than a right to a trouble-free life and a painless death; nothing that can live its life without violating the equal rights of others ought to be prevented from doing so, and imprisonment, castration, slavery and death are all prima facie wrongs even if no "pain" is suffered. On the other hand we are no closer to seeing what exactly the real rights of all subjects-of-a-life might be; it will not do to suppose that they all have just those rights that are popularly supposed to be human rights, because we have yet to see whether such human rights can be granted to all such creatures.

This latter point is one that I have argued at length elsewhere (Clark 1979, 1987); it seems to be impossible to suppose that literally all such subjectsof-a-life have just those rights against arbitrary arrest, killing, even misuse that human beings have been supposed to have. A right is a claim that ought to be defended by governmental (or any other) action; whose claim is to be defended as between worm and blackbird, blackbird and cat, wildebeest and lion, whale and Inuit? To protect one creature is to make life impossibly difficult for another; if their rights are equal, none has an unlimited right to life, and none can claim to be injured (in the sense that his rights are violated) if he is killed. The rights that all subjects-of-a-life could have seem to be the very minimal ones of extreme right-wing liberalism, namely the right to live as long as one can manage, without any corresponding right of assistance from others. Prey animals have a right to evade pursuers, and predators have a right to carch them; neither does any wrong, and neither does any rational lawenforcement agency in the vicinity if it simply ignores the problem. Our right as mere subjects-of-alife consists merely in the right to live under the Law of the Jungle and, at best, not to have one's options radically and deliberately confined. The law that should be enforced would be something like the supposed "balance of nature" (though one might reasonably have doubts even about that).

Other difficulties with Regan's argument will doubtless be picked up by Frey, notably that there is some conceptual problem with the very notion of a "subject" distinct from the experiences that it has or (on other views) that compose it. Regan needs some such idea of a subject that is more than a mere stream of sensations and perceptions but does little to clarify it. Nor is it easy to insist that what matters about a creature (so far as its moral status is concerned) is its essential nature rather than the web of relationships and approved meanings in which it has its being; it may be true that chimpanzees and imbeciles have very similar mental capacities (though it is actually an error to suppose that chimpanzees are mentally defective), but their meanings in (human) society are not the same. We need more argument than Regan gives to insist upon the "real" as against the "social" nature of a creature as what defines its moral status. As it happens, I agree with Regan's account, so far as it goes, and regret the tendency in some recent philosophical writing to eliminate the notion of the Self. Without the Self we have no final defence against an aggregative and totalitarian utilitarianism a lot more simple-minded than Frey's!

Regan believes that all animals who can plausibly be said to live their lives, to be something more than a mindless aggregate of sensations and perceptions, ought to be treated as ends in themselves, not subjected to conditions that they would nor choose for themselves with a view to their own goals in life. This is not because they "have rights" in some metaphysical sense, as if the rights they had were the reasons that they ought not to be treated disrespectully. To say that they have rights is simply to say that they ought to be treated thus and so, not to give a reason for this rule. The reason they should be so treated, and the law invoked to defend them in the peaceful enjoyment of the same liberties as ourselves, is that they do not differ from "us" in morally relevant ways. I may be a better mathematician than Clever Hans (because he wasn't a mathematician at all), but being bad at mathematics is not normally a good reason to deny one civil rights! The creatures we live with, oppress and often admire have their own purposes and lifestyles that deserve as much consideration from us as we deserve from others. As far as our relation with "tame animals" goes, I am in complete agreement with Regan: I too believe that we treat such creatures wrongly when we systematically deny to them the sort of respect and care that we are so eager 
to have lavished on ourselves. Where I differ from him is in doubting the fundamental postulate of "liberalism," as I have defined it, namely that there is a difference in principle between what is and what is not one's "own" business. Rights play no large part in my political philosophy, and I do not care to express my own concern for animals in terms of their putative "natural rights," especially as the only rights that literally all such animals could have are not very significant. I have no right not to be eaten by a crocodile, and neither does anything else, simply in the abstract, and a sheep has no right not to be eaten by me; I do sometimes have a civil right against the river police that they should make the river as safe as possible, and others than I have thought it a poor reward for the giver of wool and cheese to be killed and eaten when we have no need of flesh foods. What concerns me most are not abstract natural rights but concrete historical ones. The rights of British beasts, as I remarked some years ago (Clark 1979), are more important for their lives and liberties than the "natural rights" of all creatures under heaven. Those latter rights, against each other or against Heaven, can only be for a relatively stable and unpoisoned biosphere within which they can get on with their living (and their dying). That does not promise any individual security, though it is not quite irrelevant to the moral questions about our present dealings with the nonhuman (see Clark 1987). I should add that I do not share Regan's apparent conviction that our only important duties in these matters rest upon the sort of rights that he imputes to subjects-of-a-life.

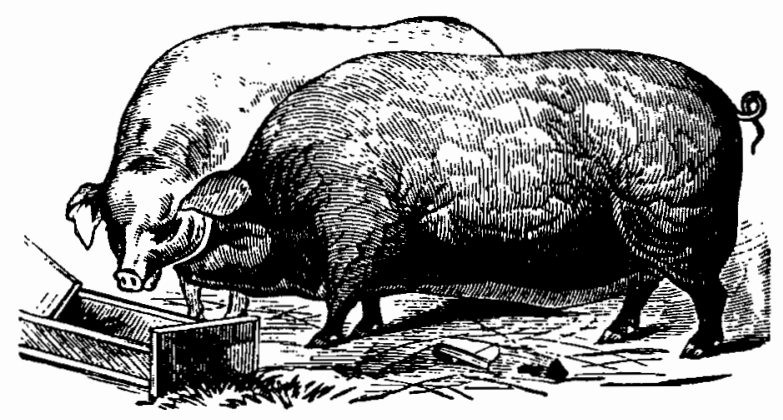

Carol Belanger Grafton,

Old-Fashioned Animal Cuts.

New York: Dover, 1987
III

So what is my quarrel with Frey or with the mass of traditionally-minded people? Most people, no doubt, still believe that there is a radical difference of natural kind between humans and all other creatures, and even sometimes speak (in the face of all the biochemical and behavioural evidence) as if chimpanzees were more like earthworms than they are like humans; our predecessors have openly, and our contemporaries covertly, insisted that humankind is a different Kingdom from Animals and from Plants alike, with a radically different sort of soul. Those who have held this theory have been able to add that even "defective" members of our species are proper humans "underneath," that all apparent resemblances between our species and any other are merely illusory, and that humankind is patently superior to both other Kingdoms. Everything in the world is "for our sake," and we do no wrong in making use of it.

This was never, I must insist, a Christian dogma; it was a doctrine, welcome enough to ordinary human sensibility, formulated by Greek philosophers and adopted by some Christian thinkers as a way of insisting on their distance from Manichean doctrines about the world and our place in it. It was thought to be dangerous to suppose that we were "like animals" because "behaving like animals" was equated (wrongly) with selfish and materialistic concerns (see Clark 1982, 1983). It was thought to be dangerous to advocate abstention from flesh foods and the like because this was taken to imply that the world of nature was evil, not such as to be decreed by a benevolent creator. There was even a certain strength in this: perhaps it is indeed because we are unlike other animals that we can give them more consideration than they could normally give others, and perhaps it would be wrong to insist too strongly that the world as it is is evil (for the reasons mentioned above: we cannot even begin to establish laws for the lion and the ox, the blackbird and the worm and the cat). For better or worse we are stuck with the world and with our particular problems.

That Humankind is a different Kingdom is now unbelievable for most of us; the capacities and interests that we have are recognizably those of a terrestrial mammal from primate stock, with special 
(and related) gifts for grammatically structured language, cooperative endeavor and empathetic identification. Those specifically human capacities are very widely spread in our biological species, but "a species" is not a natural kind, and we have no $a$ priori reason to suppose that all our conspecifics are thus characteristically "human" (Clark 1988a) or that no other creatures have any trace of those specific traits. The very philosophers of Greece who identified the adult rational human being as the primary moral object also acknowledged that our moral sensibility develops from the familial and friendly concerns of other animals. We are moral because we are mammalian, long before we are also rational enough to reconsider our roots.

So where do our moral loyalties lie? Primarily with our children, our clan-mates and our domestic companions. We begin to be moral beings not by rational intuition of the form of Rational Humanity, as though adult rational humans were the paradigmatic moral objects, but by local and familial concern for our children, our friends, our domestics. The idea that rational adults are the primary rightsholders and children and other dependents are "only" sentimentally protected is absurd; it is they who are most protected by law and public opinion and parental sentiment in every human community (Clark 1988b). The first charge upon our moral account is to care for those in our care, to be loyal to those with whom we have bonds of affection and familiarity. Only a doctrinaire humanism can ignore the obvious fact that amongst those domestic ties are ties of friendship, family loyalty to animals not of our species. We have carried to an extreme what is always an animal possibility: to adopt, affiliate, domesticate creatures who are not members of that group of interbreeding populations of which we are members. Historically and philosophically children and dogs have rights before any notionally human stranger does. Certainly improved knowledge of that human stranger, or the class of such strangers, enables us to imagine a friendlier relationship developing, and accords her rights of a similar sort but that does not put her above the creatures of our immediate household. It is because we have experience of getting on with creatures of a seemingly disparate kind that we can get on even with human strangers; treating them "like animals" is not always a bad idea!
My first principle, then, is simply to insist on the primacy of the historically founded household and tribal group, a community of many ages, sexes and species. Dogs, horses, cats and cattle are members of one and the same society with us - granted that they have not "chosen" to be so, and may have radically different concepts of what society it is that they share in, but that is true of us as well. That is why I do not share the view of some animal liberationists that domestication is of its nature tyrannical and that all domestic "pets" should be released to make their own ways in the world. That would, in my view, be as pointless and as cruel as it would be to throw out your children or refrain from disciplining and educating them on the specious ground they they have not "chosen" to be born into our particular family and culture. I do not think it an infringement of liberty to educate and give moral training to a child or to a "pet." What is offensive is to deny to them the right to participate in social order on such terms as allow them to form friendships and follow vocations in ways suitable to their age and kind. The ideal for which liberals are groping is not that of independent action without any obligation of care or cooperation but the open fraternity of mutually respectful well-wishers.

My first point, that is, is that "animals" are not all outside the community of which we are a part. The self-styled animal-lover who prefers to have his dog killed rather than have her trained to live peacefully and usefully in society or take the trouble of finding her a temporary home while he goes on holiday (see Hearne 1987) betrays a fundamental loyalty, reveals a thoroughly mean spirit. That cannot possibly be a matter of indifference to the rest of us; we cannot afford to have such selfish, stupid and disloyal folk imagining that they are all o.k. We acknowledge as much by rearing our children to be "kind to animals" and to fulfill their obligations to them. We often misjudge kindness and misidentify our obligations, but our main problem is, as it has been for most human communities, that we thereby establish habits of care and concern for animals that we then make it our business to extirpate or neutralize in other areas (Diamond 1979).

The confusion goes back a long way: hunting tribes who genuinely "must" kill animals for food and clothing must also establish a rapport with the 
creatures that they hunt. They may even introduce some of those prey animals into their households as honored guests and friends and certainly feel respect for the wild things. Their projections and empathetic identification with the animals they hunt creates a Lord of the Animals who must then be propitiated. The animals must be seen to "consent" to their deaths and must be compensated for their troubles.

\section{Society does not exist to serve the purposes of self- seeking rational adult individuals but to maintain the households within which we all grow up.}

One of the roots of religion is blood-guiltiness, the need to balance empathetic identification, aesthetic admiration and the needs of the tribe. Once animals are "domesticated" (which is to say, affiliated) and their treatment gradually veers away from anything that they might be presumed to have bargained for, it becomes necessary for our peace of mind to suppose that the gods have "given them to us" (though even at this stage there are usually conditions on the gift, as that we must not eat the blood, which is the life). In the final and fatal confusion of modern atheistic humanism, the notion that the animals are "our's" to do with as we please is maintained even in the absence of a worthy giver. It is at this point that people, and especially those initiated into the scientific community, begin to talk patent and antievolutionary nonsense to the effect that "animals" are quite unconscious. Descartes himself advanced as a reason for believing this that if it were false, we should have to agree that many of our practices were cruel and unjustified, and therefore change them (Rosenfield 1941).

The excuses and rationalizations that we have offered for regarding what we do to "animals" as beyond serious moral consideration are wearing thin. Those who work cooperatively with domestic animals are well aware that they occupy the same "moral universe" as ourselves, though with differing capacities and obligations. The corruption of modern farming and experimental practice (as well as the corruptions often evident in the treatment of "pets") at least has the merit of alerting us to the moral problem we face, of forming and consolidating a genuine community of many ages, sexes and species. As we turn aside from our mistaken concentration on the rational adult as the paradigmatic moral object and the norm of our species life, we can begin to see that it is not impossible also to make room for those "marginal" cases that I mentioned before. Children, imbeciles, lunatics and the senile are not marginal to society, any more than domestic animals. Society does not exist to serve the purposes of selfseeking rational adult individuals but to maintain the households within which we all grow up.

It is that set of households, that continuing city with its historically formulated rights and obligations, that gives us the best model for the world at large. For it is no part of my principles that moral obligation stops at the threshold of actually cooperating cities. We live within the wider world; our generation is better able to appreciate than almost any other since pagan times that the dynamic order of the cosmos, especially as it is represented here-now in the terrestrial biosphere, is the earthly home of all value, that its survival is of desperate concern to every living creature, and that insofar as (some) humans are able to reach beyond their parochial boundaries to contemplate and admire and serve the cosmos we do indeed show our special contribution to that same cosmos. The final context of our worldly activity is not our immediate household or nation-state, nor yet the socio-political nexus of suffering humanity, but the whole earth. Ir is of that "Great City, whose author and founder is God," so Berkeley said (1948, 3, 129), that we should think ourselves citizens. That principle of mutual attraction which draws us "together in communities, clubs, families, friendships and all the various species of society" $(7,226)$, leads on to a loving appreciation of the whole earth and the spirit that guides its doings. "The poet says, dear city of Cecrops, and will you not say, dear City of Zeus?" (Aurelius 4.23 ). We must act by such rules as are necessary for the continued health and being of the terrestrial biosphere. In saying this I do not, as some have supposed, make a radical break with tradition. 
On the contrary, the very founders of liberalism based their political philosophy precisely on a recognition of that cosmic viewpoint and the splendor and moral demandingness of the living world. Individual right, Kipling's "leave to live by no man's leave underneath the Law," and private property were defended as the likeliest way of enabling a society of freemen to subsist in mutual harmony and cultivate their virtues: if we each had some portion of the land to tend, we would be less likely to fall prey to tyrants, and the land itself would prosper. What we owned, however, was not the land itself but the lawfully acquired fruits, and we owned these only for their lawful use. "Nothing was made by God for Man to spoil or destroy" (Locke Treatises 2.31: 1963 p. 332). Individual liberty rested on the value God placed in every soul as a unique expression of His glory, such that any despotism, however benevolent in purpose, must issue in a decline of valuable diversity. Each of us has a profound and vital interest in the virtue of our fellow citizens and in the continued viability of the ecosystems within which we live.

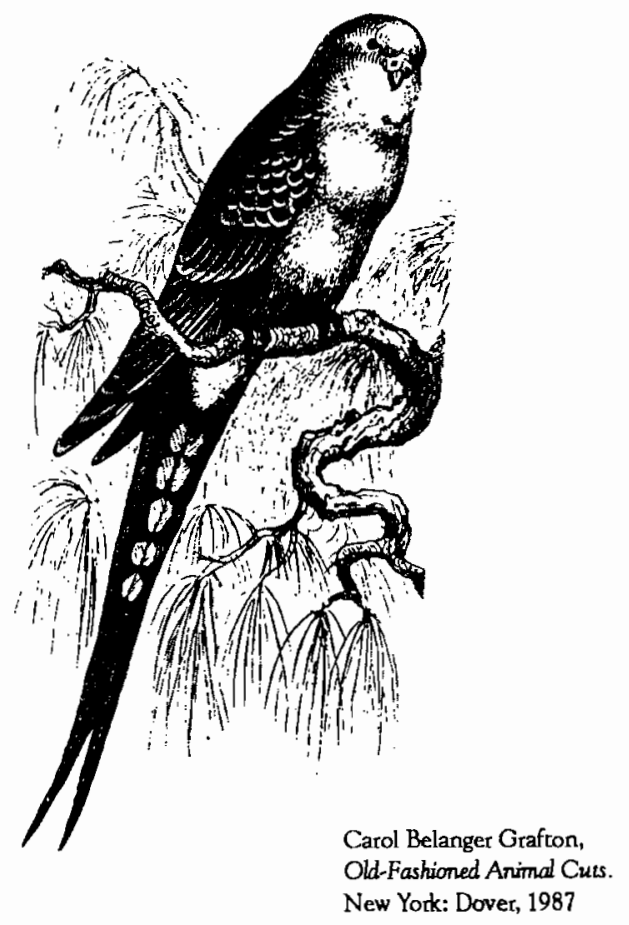

Aldo Leopold's vision has been the inspiration of much recent environmentalism:

We abuse land because we regard it as a commodity belonging to us. When we see land as a community to which we belong, we may begin to use it with love and respect ... That land is a community is the basic concept of ecology, but that land is to be loved and respected is an extension of ethics (Leopold 1968 p. viii).

It was precisely because the whole world was worth admiring that our human capacity to admire it was also admirable. Ecology, considered not as a supposedly value-neutral science but as the study of earth's household, is founded on just the loving appreciation and would-be civil companionship that the ancients endorsed. The moral sensibility born in our household and cities must be extended to the whole earth, and we must ask ourselves how the one Creator would require us to act for the benefit of His creation.

A wise man ... does not look upon himself as a whole, separated and detached from every other part of nature, to be taken care of by itself and for itself. He regards himself in the light in which he imagines the great genius of human nature, and of the world regards him. He enters, if I may say so, into the sentiments of that divine Being, and considers himself as an atom, a particle, of an immense and infinite system, which must and ought to be disposed of, according to the conveniency of the whole. (Smith 1976, p. 276: VII 2.1.20).

Frey has often retorted to me that my appeal to the One Creator, to God, can have no significance for an atheist like himself. I am not sure that this need be entirely true; the appeal, in one sense, is simply to ask by what rules the biosphere could be conceived to be run, what could intelligibly or usefully be demanded of us all. It seems fairly clear that current policies in farming, deforestation, industrial pollution and the like cannot long continue, and that we would be well advised to ask what sustainable practices are available to us. These will not guarantee rights to life, liberty and the pursuit of happiness in anything like the traditional 
sense to "all creatures in the world," but I have already said that I expect no such rights. Nor does my appeal rest of necessity upon any realistic belief in a transcendent deity. That the cosmos as a whole, and especially the terrestrial biosphere here-now, is admirable, is the global context of all our admirations, is expressed by reference to the divine underlying structure of that cosmos. I do not thereby commit myself to any view about the nature of any concern felt by "the cosmos as a whole" for my life or for any human or other life. Sperry's claim that "the grand design of nature perceived broadly in four dimensions to include the forces that move the universe and created man, with special focus on evolution in our biosphere, is something intrinsically good that it is right to preserve and enhance and wrong to destroy and degrade" (Sperry 1983: 22) does not consciously rest, as far as I can see, on any kind of orthodox metaphysical theism, though he thereby expresses part of what Kohak does in more traditional terms:

Are we a higher species? A disinterested observer, coolly examining the evidence and assessing humanity's impact upon the globe, would not be likely to come to that conclusion ... At best we are one species among others. But then, what justifies the totally disproportionate cost of our presence? Ask it for once without presupposing the answer of the egotism of our species, as God might ask it about his creatures: why should a dog or a guinea pig die an agonizing death in a laboratory experiment so that some human need not suffer just such a fate? (Kohak 1984, p. 92).

But I may as well come clean. I do indeed believe that there is a God, and that it is our failure to acknowledge that God which is as the root of our confusion and degradation in epistemology as well as in morals. I can well understand that people who believe the world to be the product of blind and indifferent powers should think that it can be given value only by our wishes, though I do not understand how anyone can take her own particular wishes very seriously when it is clear that she could have had quite different ones and not made any error. "What beauty can be found," Berkeley's Euphranor inquires in criticism of the high-minded atheist, "in a moral system, formed, connected and governed by chance, fate or any other blind unthinking principle?" (Berkeley 1948, 3, 128). But perhaps if we have no alternative, we shall simply have to put up with that. What I do not understand is how anyone who supposes that the Origin is blind, lazy and inane can think that it is at all likely that we hairless primates on a heap of rubble should be able to find out how the world works. The one hypothesis on which this would be at all probable is that the world has been set up for us to understand and enjoy (or we have been set up to understand and enjoy it). Only if the pattern of things is a pattern imprinted in our hearts - as of course the founding fathers of modern science, like Galileo, actually believed - can we rationally expect to find that pattern. And in thus discovering how the world is intended we also find how we are intended to be. If our special human gift is to contemplate and serve the cosmos, if we are, in Heidegger's phrase, "servants of being," it behooves us to attend more carefully than we yet have to the other creatures that share the world with us, amongst whom we live both at a domestic and at a more cosmic level.

In brief we ought to change our present ways not simply because the present ones involve too many creatures in pain and distress we do not need to cause (though that is true enough) nor because all creatures with lives to live ought to be permitted or even helped to live them (though that too is broadly true) but because the households in which we first learn ethical behavior already include nonhumans whom we ignore and abuse because we allow ourselves to be influenced by theories and excuses that we know full well are false and because the whole earth that it is our duty and our joy to serve requires that all kinds and conditions of living creature have their own lives and territories. You may, if you choose, regard my references to God as myth-making of the unserious kind that some commentators have sometimes thought that Plato used to indulge. But in the interest of a rousing conclusion, I reaffirm that I mean just what I say. Those who muzzle the ox that treads out the corn, plough up the wilderness, hunt species to extinction and consume the lives of those whom God has given to us to care for should stand in fear of the judgment. "Then shall the land enjoy her sabbaths, as long as it lieth desolate, and ye be in your enemies' land; even 
then shall the land rest and enjoy her sabbaths. As long as it lieth desolate it shall rest, because it did not rest in your sabbaths when ye dwelt upon it" (Leviticus 26.34ff).

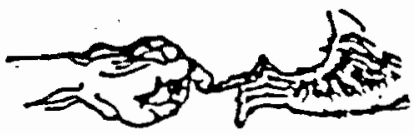

\section{$\underline{\text { References }}$}

Berkeley, G. 1948, Collected Works, eds. A.A. Luce and T.E. Jessop (Edinburgh Universiry Press: Edinburgh).

Clark, S. R. L. 1977, The Moral Status of Animals (Clarendon Press: Oxford; pbk. 2nd ed. 1984).

22, pp. $171 \mathrm{ff}$.

1979, "The Rights of Wild Things," Inquiry

1983, "Humans, Animals and 'Animal Behavior'," H. B. Miller and W. H. Williams, Eds., Ethics and Animals (Humana Press: Clifton, New Jersey), pp. 169ff.

1984, From Athens to Jerusalem (Clarendon Press: Oxford).

1985a, "Hume, Animals and the Objectivity of Morals," Philosophical Quarterly 35, pp. 117-33.

1985b, "The Rights of the Wild and the Tame," Chronicles of Culture, Vol. 9, No. 8, pp. 20-22.

Oxford).

1986, The Mysteries of Religion (Blackwells:

1986b, "God-appointed Berkeley and the General Good," J. Foster and H. M. Robinson, eds., Essays on Berkeley (Blackwell: Oxford), pp. 23-53.

1987, "Animals, Ecosystems and the Liberal Ethic," Monist 70.1, pp. 114-33.

1988a, "Is Humanity a Natural Kind?," T. Ingold, ed., What is an Animal? (Unwin Human: London), pp. 17-34.

Scarre, ed., Children, Parents and Politics (Cambridge University Press: Cambridge).
Diamond; C. 1978, Eating Meat and Eating People: Philosophy 53.

Frey, R.G. 1983, Rights, Killing and Suffering (Blackwell: Oxford).

Hearne, V. 1987, Adam's Task: Calling Animals by Name (Cape: London).

Hume, D. 1902, Enquiry Concerning the Principles of Morals (Clarendon Press: Oxford).

Kohak, E. 1984, The Embers and the Stars (University of Chicago Press: Chicago).

Leopold, A. 1947, A Sand County Almanac (Oxford University Press: Oxford).

Locke, J. 1963, Two Treatises of Government, ed. P. Laslett (Cambridge University Press: Cambridge).

Nicholson, E.B. 1879, The Rights of an Animal (Kegan Paul: London).

Regan, T. 1983, The Case for Animals Rights (Routledge \& Kegan Paul: London).

1986, "The Bird in the Cage," Between the Species 2., pp. 90-99.

Rosenfield, L. C. 1941, From Beast-Machine to ManMachine (Oxford University Press: New York).

Rothbard, M. 1982, The Ethics of Liberty (Humanities Press: Atlantic Highlands).

Salt, H. 1980, Animals' Rights Intro. P. Singer (Centaur Press: London).

Singer, P. 1976, Animal Liberation (Cape: London).

1985, "Ethics and Animal Liberation," In Defence of Animals, ed. P. Singer (Blackwell: Oxford), pp. $1-10$.

Smith, A. 1976, The Theory of Moral Sentiments, eds., D. D. Raphael \& A. L. Macfie (Clarendon Press: Oxford).

Sperry, R. 1983, Science and Moral Priority (Blackwells: Oxford). 